\title{
Film Translation in Chinese Mainland and Taiwan - A Theoretical Exploration of Intercultural Communication across the Strait
}

\author{
Gina Chiu Chang \\ Department of Foreign Languages and Literatures, School of Humanities \\ Tsinghua University, Beijing, China
}

Received: 27-03- 2014

doi:10.7575/aiac.ijclts.v.2n.3p.24
Accepted: 02-04- 2014

Published: 01-07- 2014

\begin{abstract}
The film is a means of mass entertainment which has become part of our daily lives. As more and more English films are imported to China, intercultural communication becomes an important component in the mass media. It allows film translators to make adaptation based on the source text in order to create accessible text which fulfills the need of the target community. However, due to the eminent cultural differences, film as a branch of literary translation, when translated, critical factors such as history and tradition must be carefully reviewed. Film translators are required to make appropriate adaptations based on the source text, retain the intended message of the source language, and eliminate the cultural gaps so that the target language audience can better comprehend and appreciate the film correctly. However, even in Chinese speaking areas such as Chinese Mainland and Taiwan the linguistic translation strategies adopted in the same film are disparate. In order to improve the quality of film translation, we need to have some systematic theories to guide translators on how to make flexible adaptations. Hoping to provide a new perspective for common film translation studies in Chinese Mainland and Taiwan, this explanatory study of film translation focuses on the different methods adopted by translators during the process of translating a foreign film in Chinese Mainland and Taiwan through a theoretical exploration of the translation, attempting to find a norm and to formulate a guiding theory for translation in Chinese speaking areas. This paper attempts to construct a theoretical framework for this intercultural production. It first gives a brief introduction of the state of the art in film translation, its gaining popularity, and its empowerment potentials. Then the paper proposes to integrate different theoretical traditions in translation studies in order to formulate a conceptual and theoretical framework that could be used to better comprehend the social dynamics surrounding subtitling, editing, revising and marketing strategies. Theory of functional equivalence, relevance theory and reception theory are critically reviewed and integrated. It also argues that audiences and translators are playing a decisive role in film translation.
\end{abstract}

Keywords: film translation; audience-orientedness; relevance theory; functional equivalence, reception theory

\section{Introduction}

Globalization has made the exchange between different cultures easier, and more efficient. With the growth of the broadcast networks and multimedia, Hollywood films have become a big hit around the globe in recent years, and consequently, film translation has become increasingly important. Film lovers like films in the original for various reasons. The most common reason is to hear the real voices of the actors, and to learn a foreign language. This phenomenon makes it possible for audience to have close contacts with the foreign culture. Film then becomes the best channel for cultural transfer. However, the problems caused by low-quality translations or mistranslations often reduce the effect and quality of the cultural transfer. When such issues are present, the audience sometimes has difficulty in understanding culture-specific elements that prevent them from fully appreciating foreign films.

Film translation plays an extremely important role in the distribution of films overseas. Due to obvious cultural differences, when a film is translated, critical factors such as history, tradition, and audience must be carefully reviewed. Hence intercultural communication becomes an important component in the mass media. It allows translators to make adaptation based on the source text in order to create more accessible text which fulfill the need of the target community. However, restricted by time, in most film translation, the true meaning of dialogue is often misinterpreted or overlooked. Additionally, many subtitles are sometimes out of synchronization with the pictures displayed on the screen, thus many lines are left untranslated or interjected with irrelevant dialogues which have nothing to do with the plot of the original story. Poor translations and mistranslations will obscure the original meaning conveyed and compromise the beauty depicted in the original works. In the worst case, such translations might confuse and mislead the audience, causing serious misunderstanding of the film. As a result, the audience may reject and misunderstand the dialogue and other key components found in foreign culture. Hence concerning the popularity and the growing need for film translation, translation theories and their application in this field should be carefully reviewed as a whole.

2. Film Translation: Past and Present

In the West, as early as the mid-first century BC translation had come to be thought of as definitively literal (Baker, 2001: 125). However, Nabokov's assertion in 1955 argues that the translator has the duty to reproduce with absolute the 
whole text, and nothing but the text. Thus, it is important that the translator make adaptations toward the organizations of the linguistic expression in order to accommodate target audience's thinking patterns.

Renowned scholars like Holmes (1988), Gottlieb (2000), and Gambier (2003), focused their studies on film translation, emphasizing the process of translating the text to screen. Meanwhile others, like Nedergaard-Larsen (1993), Aixelá (1996), and Gutt (2000), examined the problem of cultural differences found in film translation. Gutt proposes:

if we ask in what respects the intended interpretation of the translation should resemble the original, the answer is: in respects that make it adequately relevant to the audience, that is, that offer adequate contextual effects; $[. .$.$] it$ should be expressed in such a manner that it yields the intended interpretation without putting the audience to unnecessary processing effort (Gutt, 2000: 107).

Film is also a purposeful activity for bonding different cultures. In the field of film translation, "a culture-specific reference does not exist of itself, but as the result of a conflict arising from any linguistically represented reference in a source text which, when transferred to a target language, poses a translation problem due to the nonexistence or to the different value (whether determined by ideology, usage, frequency, etc.) of the given item in the target language culture" (Aixelá, 1996: 57). According to Aixelá (1996), a culture-specific reference can be identified only when referred to a particular source language and a particular target language. However, in most cases, the film translator does not have active competence in both the source languages and the target languages, and lacks knowledge of cultural information. Thus, the culture-bound references became omitted, or untranslated, and it becomes more difficult for the target audience to understand the culture-bound contents.

Currently, there are still no concrete sets of global principles on translation theories to guide the study of film translations. Most of the studies conducted focused on particular translations of work itself, exploring the special techniques and methods applied. The Chinese scholars devoted to the study of film translation are Zhang Chunbai (1998), Zhao (2000), Li (2001), and Qian (2004). They did their researches on film translation from different perspectives, but there is no comparative study across the strait in film translation yet.

\subsection{Film Translation Trend in Historical Perspective}

The history of Chinese-language cinema has separate threads of development. Before Chinese Mainland was fully liberated in 1949, Chinese cinema had its slow and difficult start under the influence of Hollywood and European imported films. The first sound film from the United States was introduced into Chinese Mainland in 1929. However, full-length film translation in Chinese Mainland started formally in the late 1940s. Changchun Film Studio, the biggest studio of Northeast China, was the first to start film dubbing in 1949. Next, in 1950, the Shanghai Film Studio set up a dubbing department and dubbed its first film which was a Russian film entitled The Little Hero. In 1978, after the Mainland opened to the outside world, there began a continuous boom of film translation. As a result, the government loosened up its control over the import of foreign films.

The China Film Distribution Company, which is Chinese Mainland's sole film import and distribution institution, generally adhered to the following principles when importing foreign films:

- Films that are related to violence, pornography, political or religious propaganda are excluded

- The Company stipulates that American films should not exceed 50\% of all imported films (Qian, 2004: 54).

There have been significant changes in Chinese foreign film policy in the last decade. Despite the Chinese central government's limitation on imported films, and new policies to encourage Chinese businesses to invest in film production, foreign films continue to represent a considerable share of the Chinese market.

Table 1. Production, Dubbing and Showing of Films in Chinese Mainland (2000-2011)

\begin{tabular}{|c|c|c|c|c|c|c|c|c|}
\hline \multirow[t]{7}{*}{ Year } & \multicolumn{4}{|c|}{ Production and Dubbing } & \multicolumn{4}{|c|}{ Film Showing } \\
\hline & & Local Films & & Dubbed & Showing & Local Films & Spectators & Imported \\
\hline & Feature & Cartoons & Popular & & & & & $\begin{array}{l}\text { Films } \\
\text { of which }\end{array}$ \\
\hline & Films & & Science & Films & & \# Cinemas & (10 000 & \# Cinemas \\
\hline & & & Films & & & & & \\
\hline & (film) & (reel) & & (reel) & (10 000 & and Theatres & person-times) & and \\
\hline & & & & & times) & & & Theatres \\
\hline 2011 & 25 & & & 358 & 76 & 75 & 2792 & 2668 \\
\hline 2010 & 19 & 2 & & 151 & 55 & 54 & 2289 & 2174 \\
\hline 2009 & 11 & & & 284 & 44 & 43 & 1938 & 1844 \\
\hline 2008 & 17 & 8 & & 248 & 35 & 34 & 1456 & 1381 \\
\hline 2007 & 9 & & & 211 & 33 & 32 & 1385 & 1277 \\
\hline 2006 & 9 & & & 312 & 27 & 26 & 1254 & 1173 \\
\hline 2005 & 13 & & & 183 & 28 & 26 & 1509 & 1323 \\
\hline 2004 & 12 & 1 & & 248 & 24 & 23 & 1364 & 1183 \\
\hline 2003 & 9 & 10 & 2 & 216 & 20 & 19 & 971 & 870 \\
\hline 2002 & 10 & 2 & 11 & 204 & 20 & 17 & 1198 & 921 \\
\hline 2001 & 12 & 2 & 8 & 237 & 18 & 17 & 1553 & 1315 \\
\hline 2000 & 10 & 20 & 12 & 438 & 18 & 17 & 1794 & 1452 \\
\hline
\end{tabular}


Note: Data in this table are provided by Shanghai Municipal Administration of Culture, Radio, Film \& TV.

In Taiwan, silent film was first introduced by the Japanese in 1901. However, due to the political situation, the language barrier made films exclusive to either Taiwanese dialect audiences or Japanese audiences. In 1927, the first film with sound appeared. All films still had to be subtitled according to the colonizer's language: Japanese. A significant change occurred after Japanese colonization. With the rule of Chinese government after World War II, the cinema was used as an instrument by the KMT party authority. There were only two film agencies: 1) The Nationalist party's film agency: Farming and Education Film Company, and 2) The provincial government's film agency: Taiwan Film Culture Company. Censorship forces, linguistic and tax policies coming from the government restricted the development of commercial films. The film industry existed only for a political function. A rapid modernization in Taiwan began in the 1960s. It was in the 1980s that the cinema began to transform from under the control of authority to authorship, and that Taiwan nativism from the aboriginal perspectives began to receive attention (Yeh \& Davis, 2005).

In contrast to the limitations found on the import of foreign films in Chinese Mainland, foreign films take up the majority of the film market in Taiwan. However, there has been a change in the film market distribution in Taiwan. As shown in the following table, there has been a significant increase in the production of local films in Taiwan in the past decade.

Table 2. Film Market Distribution in Taiwan (2000-2011) ${ }^{2}$

\begin{tabular}{|c|c|c|c|}
\hline \multirow[t]{2}{*}{ Year } & Local Films & $\begin{array}{l}\text { Imported Films from Hong } \\
\text { Kong and Chinese Mainland }\end{array}$ & Other Imported Films \\
\hline & \# of Films/Percentage & \# of Films/Percentage & \# of Films/Percentage \\
\hline \multirow[t]{2}{*}{2011} & 65 & 37 & 391 \\
\hline & $13.18 \%$ & $7.51 \%$ & $79.31 \%$ \\
\hline \multirow[t]{2}{*}{2010} & 50 & 39 & 391 \\
\hline & $10.42 \%$ & $8.13 \%$ & $81.45 \%$ \\
\hline \multirow[t]{2}{*}{2009} & 48 & 35 & 348 \\
\hline & $11.14 \%$ & $8.12 \%$ & $80.74 \%$ \\
\hline \multirow[t]{2}{*}{2008} & 36 & 31 & 351 \\
\hline & $8.61 \%$ & $7.42 \%$ & $83.97 \%$ \\
\hline \multirow[t]{2}{*}{2007} & 42 & 32 & 342 \\
\hline & $9.44 \%$ & $7.75 \%$ & $82.81 \%$ \\
\hline \multirow[t]{2}{*}{2006} & 27 & 43 & 302 \\
\hline & $7.26 \%$ & $11.56 \%$ & $81.18 \%$ \\
\hline \multirow[t]{2}{*}{2005} & 40 & 58 & 309 \\
\hline & $9.83 \%$ & $14.25 \%$ & $75.92 \%$ \\
\hline \multirow[t]{2}{*}{2004} & 25 & 48 & 246 \\
\hline & $7.84 \%$ & $15.05 \%$ & $77.12 \%$ \\
\hline \multirow[t]{2}{*}{2003} & 14 & 48 & 222 \\
\hline & $4 \%$ & $16 \%$ & $80 \%$ \\
\hline \multirow[t]{2}{*}{2002} & 21 & 45 & 246 \\
\hline & $6.73 \%$ & $14.42 \%$ & $78.84 \%$ \\
\hline \multirow[t]{2}{*}{2001} & 17 & 105 & 222 \\
\hline & $4.94 \%$ & $30.52 \%$ & $64.54 \%$ \\
\hline \multirow[t]{2}{*}{2000} & 38 & 128 & 280 \\
\hline & $8.52 \%$ & $28.7 \%$ & $62.78 \%$ \\
\hline
\end{tabular}

\footnotetext{
${ }^{1}$ Statistics Shanghai. 22.13 Production, Dubbing and Showing of Films (1978 2010)[EB/OL]. [2012-02-20]. http://www.stats-sh.gov.cn/tjnj/nje11.htm?d1=2011tjnje/E2213.htm. http://www.taiwancinema.com/IVaTrackback/trackback.asp?id=132.

${ }^{2}$ Taiwan Cinema. [EB/OL]. (2012 01-16) [2012-02-20].
} 
On the other hand, at the turn of the 20th century, the United States established its position by focusing on the development of its cultural and economic progress through films. American film companies flourished between the 1930s and the 1950s. American film industries dominated the entire film industry as the recording equipment were being monopolized. It is also then that the American values began to be spread all over the world through Hollywood productions.

\subsection{Key Issues in Film Translation Today}

Film is a fairly new genre of literary works. It is a means of mass entertainment in the form of sound and images composed of an artistic language with aesthetic appeal consisting of scenes, written dialogues, recorded speech, recorded music, and recorded sounds and sound effects. Foreign films are translated to accommodate the language institution of the general public, eliminate the language barrier, and to help audience gain a better understanding of the films. However, there is no dominant or leading theory for film translators to follow. Research in the field of film translation does not keep pace with the popularity and prosperity of foreign audiovisual products.

Film translation is a form of adaptation. It is the transfer of a film from a source culture into the target culture carried out through a complicated process interwoven by language and culture which can be generally divided into two parts. The first part is composed of the transition from the original text recreation to the transadaptation of the text, and from the transadaptation of the text to translation. The second part is composed of the transition from the original text recreation to translation. Varela (1998:15) points out that as audiovisual texts receive more attention, the need to transfer such texts to other societies enhances the role of translators. Due to its visibility, film translation is easily criticized by its viewers; especially bilingual viewers. Film translators are bound to face not only the time and space constraints of the film, but also the fact that there is always someone among the viewers who can grasp considerably well what is said by the people on the screen (Trosborg, 1997: 309-338).

\section{Criteria and Principles of Film Translation}

Film is made up of frames, a series of frames is a shot, several shots make a scene and scenes make up the sequences that together constitute the film. The dialogue joins these components like beads on a single thread. Film translation involves the transmission of the information from the source language into the target language. It functions as a bridge for communication between the source language and the target language. One of the most difficult problems in film translation is found in the differences between the source culture and target culture. It requires the use of simple and clear-cut words which are meanwhile culturally loaded. People often look at things from their own perspectives. Each culture contains specific elements which are unique. Hence the conventions of film translation and reception may vary from culture to culture. There are generally four major principles to adhere in film translation: informational principle, cultural principle, aesthetic principle, and commercial principle.

Film is a reflection on life and a bridge in the communication between cultures. However, the translation of culturespecific elements in a film is often considered as one of the most difficult tasks for a film translator. Baker (1992) claimed that the expression of the source language words may express a concept which is totally unknown in the target culture, and the concepts, whether abstract or concrete, may be related to a religious belief, a social custom, or even a type of food. These culture-specific elements, culturally-loaded terms, and idioms make translation extremely difficult. Hence, the translator has to be equipped with knowledge of both cultures in order to produce a satisfying translation.

In film translation, there are different applications of translation theories performed according to the different texts involved. The decision on the theories to be applied to guide film translation is often made on the basis of several factors, such as historical contexts, traditions, the technique which the audience is accustomed to, and the position of both the target and the source cultures. Nida points out that there are three critical factors in translation: "(1) the nature of the message, (2) the purpose or purposes of the author and, by proxy, of the translator, and (3) the type of the audience" (Nida, 1964: 127). He believes anything that can be said in one language can be said in another language unless the form plays an indispensable role in the messages. Translation consists in "reproducing in the receptor language the closest natural equivalence of the SL message, first in forms of meaning, and secondly in terms of style" (Nida, 1993: 88).

A film also combines diverse disciplines; each of which may have their own rules of aesthetics. In the process of translation the translator needs to translate the film in a series of creative activities. A good transmission should maintain the beauty and essence of the source message. Hence the aesthetic reception in film translation helps keep the focus on the audience's experience and the role in recreating literary works. Furthermore, people of different cultural backgrounds may share the same appreciation for a film because they are capable of drawing inferences through action, and that inferences they make as viewers or hearers follows the principle of relevance because every act of ostensive communication delivers the presumption of its own optimal relevance. By considering information that it conceives to be relevant to the message, it allows variances between the source and target texts. Relevance theory guides the film translator through allowing the audience to draw the implicit inferences from a translated film.

Commercial principle emphasizes the social and economic profits produced by the film. A film must have a commercial value. Liu (1999:49) claimed, given that the original language in the content should be translated (that is, there is commercial value), then the community should accept the target language conversion, and should not rigidly adhere to the primitive level of readability.

\section{The Translation of Film Titles}

The languages used within a race or society reflect an important aspect of its culture. Eminent cultural gap can be found between the East and the West. It is often believed that when compared to the West, the Chinese culture is rather demure and conservative. However, there is a cultural gap even among Chinese speaking areas such as Chinese 
Mainland and Taiwan. Such difference can be found immediately from its translation of film titles. Difference and similarities exist in Chinese Mainland and Taiwan due to various reasons such as: 1) socio-cultural reasons left from historical events, 2) different emphases on translation values, and 3) different methods adopted to accommodate to its audience which is crucial for its film promotion. Hence, the translator needs to make changes or reconstruct the film accordingly in order for the target audience to be able to infer the source text producer's intended text content and function. Trosborg (1997: ix) claimed, "conventions may differ not only between genres but also between 'identical' genres in different cultures. [...] Text-type conventions are inter-related with speech-act rules and with situational dimensions".

Mutual adaptability between Chinese and western translation theories is necessary for film translation. Adaptation in literary translation is, in its essence, a transmission of the information in the original and a reproduction of the original as an artistic work in the target language at the same time. Nevertheless, the translator's recreation is a key factor in deciding the artistic value of the translation. The traditional Chinese translation theories centers on Yan Fu's “信、达、雅”” (“faithfulness, expressiveness and elegance”). Yan Fu was among the first Chinese scholars who introduced Western philosophy systematically into Chinese Mainland through translating foreign works into Chinese such as works by T. H. Huxley, Herbert Spencer, and John Stuart Mill. The criteria for translation which he proposed laid emphasis on the role of the translator, and stressed the difficulties in translation: faithfulness in the equivalents of meanings, expressiveness in the equivalents of the styles, and elegance in the equivalents of the functions. It is to say that all translators must observe, focusing attention on the relationship of the source texts and target texts, and not merely strive for functional equivalence as proposed by Nida. Alongside, Guo Moruo is another influential Chinese scholar whose translations of foreign works into Chinese such as works by Goethe, Friedrich von Schiller, Upton Sinclair, Tolstoy, and Ivan Turgenev have earned him great popularity in Chinese Mainland. Guo Moruo once said translation is a creative work. A good translation can equal the original, or may even exceed the original. Hence, translation is not mediocre work, and sometimes it is more difficult than writing.

Following are some of the examples on the disparity ${ }^{4}$ found among some of the more well-received films in Chinese Mainland and Taiwan:

Example 1: Chronicle (2012)

Chinese Mainland:《夺命异能》

duó ming yì néng

(the lethal special power)

Taiwan:《超能失控》

chāo néng shī kòng

(super power lost control)

Chronicle is an American science fiction drama film directed by Josh Trank, and written by Max Landis based on a story by both. The plot centers around three Seattle highschool seniors who formed a bond after gaining telekinetic abilities from an unknown object. Their super powers were first used for mischief and personal gain. However, as the story developed, one of them turned towards darker purposes. Both four-character adaptations performed in Chinese Mainland and Taiwan reflects the key to the story: losing control of power. Chinese Mainland's title "duó ming yì néng", meaning "the lethal special power" leaves the viewers with the impression that lives may be lost. On the other hand, Taiwan's title "chāo néng shī kòng", meaning "super power lost control" remains more neutral.

Example 2: Extremely Loud and Incredibly Close (2011)

Chinese Mainland:《特别响，非常近》

tè bié xiăng fêi cháng jìn

(extremely loud and incredibly close)

Taiwan:《心靈錀匙》

xìn lìng yào shi

(the key for the heart)

Extremely Loud and Incredibly Close is a drama film adaption of the novel of the same name by Jonathan Safran Foer. The literal translation adopted in Chinese Mainland and the four-character translation adopted in Taiwan portrays different aspects of the film; "tè bié xiăng fêi cháng jìn", meaning "extremely loud and incredibly close" focuses on the 911 plot itself, and "xīn ling yào shi", meaning "the key for the heart" on the theme and the message of the film.

Example 3: Moneyball (2011)

Chinese Mainland:《点球成金》

diăn qiú chéng jīn

(turn the ball gold)

Taiwan:《魔球》

mó qiú

(magic ball)

Moneyball is a biographical sports drama film adapted from Michael Lewis's book of the same name. Notice Chinese Mainland often uses literal translation for most film titles. However, for Moneyball, the literal translation will be "qián

\footnotetext{
${ }^{3}$ First stated in the preface to his translation of Evolution and Ethics in 1898.
}

${ }^{4}$ Disputable disparities are italicized in the back translations. 
qiú or bi qiú", meaning "money ball, currency ball" which would seem unnatural and awkward to its audiences. The title "diăn qiú chéng jīn" is an adaptation of the Chinese idiom "diăn shí chéng jīn", meaning "turn the stone gold". It is a direct translation which is more acceptable and comprehensible to the Chinese audiences, whereas Taiwan's " $m o ́$ qiü", meaning "magic ball", again focuses on the theme and the message of the film.

Example 4: The Curious Case of Benjamin Button (2008)

Chinese Mainland: 《返老还童》

făn lăo huán tóng

(Rejuvenation)

Taiwan:《班傑明的奇幻旅程》

bān jié míng de qí huàn lü chéng

(The Fantasy Adventure of Benjamin)

The Curious Case of Benjamin Button is a fantasy drama film loosely based on F. Scott Fitzgerald's short story of the same name. Notice the four-character Chinese idiom literal translation "făn lăo huán tóng", meaning "rejuvenation" adopted in Chinese Mainland is again rather deviated from the original title. It gives away the major details that spoil the viewing experience of the film. Meanwhile the translation "bān jié míng de qi huàn lü chéng", meaning "the fantasy adventure of Benjamin" used in Taiwan keeps the essence of the film, and is yet closer to the original title.

Example 5: Live Free or Die Hard (2007)

Chinese Mainland:《虎胆龙威4.0》

hǔ dăn lóng wēi 4.0

(Tiger's Courage, Dragon's Power)

Taiwan:《終極警探4.0》

zhōng jí jüng tàn 4.0

(The Ultimate Agent)

The Die Hard action film series was first released in 1988, directed by John McTiernan, written by Steve de Souza and Jeb Stuart adapted from the 1979 novel Nothing Lasts Forever by Roderick Thorp. Live Free or Die Hard (2007) was the fourth sequel. The others of the series were Die Hard, Die Hard 2 (1990), Die Hard with a Vengeance (1995), A Good Day to Die Hard (2013). Notice both Chinese titles contain "4.0", the number of the sequel which did not appear in the original English title. The title in Chinese Mainland adheres to the common Chinese expression which contains “dragon" and "tiger"; both fierceful animals such as its appearance in 《卧虎藏龙》 ${ }^{7}$ (Crouching Tiger, Hidden Dragon) (2000). The title in Taiwan uses the term zhōng jí, meaning "ultimate"; a translation commonly found among thriller, horror, and action films in Taiwan; especially the ones that is starring Bruce Willis.

Example 6: The Day After Tomorrow (2004)

Chinese Mainland: 《后天》

hòu tiān

(The Day After Tomorrow)

Taiwan: 《明天以後》

míng tiān y̌̌ hòu

(After Tomorrow)

The Day After Tomorrow is an American science fiction disaster film by Roland Emmerich. The film depicts the catastrophic effects of global warming that results in series of extreme weather that ushers into global cooling and leads to a new ice age. The literal translation "hò tiān", meaning "the day after tomorrow" in Chinese Mainland is a handy term for The Day After Tomorrow. On the other hand, "míng tiān y̌ hòu", meaning "after tomorrow" in Taiwan is not a term, but an explanation, an indefinite reference. Influenced by the traditional four-character idiom, the four-character translation adopted in Taiwan is more direct and descriptive. Both translations contain the connotation of a day or some day after tomorrow.

Example 7: Pirates of the Caribbean: The Curse of the Black Pearl (2003)

Chinese Mainland: 《加勒比海盗 : 黑珍珠号的诅咒》

jiā lēi b̌̌ hăi dào hēi zhēn zhū hào de zǔ zhòu

(Pirates of the Caribbean: The Curse of the Black Pearl)

Taiwan:《神鬼奇航 : 鬼盜船魔咒》

shén guĭ qí hang guĭ dào chuán mó zhòu

(The Curious Cruise of the Spirits: The Curse of the Ghost Pirate Ship)

Pirates of the Caribbean: The Curse of the Black Pearl is an American fantasy adventure film based on the "Pirates of the Caribbean" ride at Disney theme parks. It was directed by Gore Verbinski and produced by Jerry Bruckheimer. The story follows blacksmith Will Turner and pirate Captain Jack Sparrow as they rescue the kidnapped Elizabeth Swann from the supernatural, cursed crew of the Black Pearl captained by Hector Barbossa. The literal translation " jiā lēi bi hăi dào hèi zhēn zhü hào de zǔ zhòu", meaning "pirates of the Caribbean: the curse of the Black Pearl" adopted in

\footnotetext{
${ }^{5}$ qián qiú / bì qiú; 钱球 / 币球; meaning “money ball, currency ball”

${ }^{6}$ diăn shí chéng jīn; 点石成金; meaning “turn the stone gold"

${ }^{7}$ wò hǔ hu cáng long; 卧虎藏龙; Crouching Tiger, Hidden Dragon
} 
Chinese Mainland is more like spoken Chinese meanwhile the free translation "shén guì qí hang guí dào chuán mó zhou", meaning "the curious cruise of the spirits: the curse of the ghost pirate ship" adopted in Taiwan is more like written Chinese.

Example 8: Catch Me If You Can (2002)

Chinese Mainland: 《我知道你是谁》

wǒ zhī dào nǐ shì shéi

(I Know Who You Are )

Taiwan:《神鬼交鋒》

shén gǔ jiāo fēng

(When the Spirits Meet)

Catch Me If You Can is an American biographical crime drama film directed by Steven Spielberg. It is based on the life of Frank Abagnale, who at the age of eighteen, successfully performed cons worth millions of dollars by posing as a Pan American World Airways pilot, a Georgia doctor, and a Louisiana parish prosecutor. His primary crime was check fraud; he became so skillful that the FBI eventually turned to him for help in catching other check forgers. The two translations reflect two diverged psychology; the former "wǒ zhī dào nǐ shì shéi", meaning "I know who you are" implying that the suspect is openly recognized, and another "shén guǐ jiāo fēng", meaning "When the Spirits Meet" less obvious. Notice the translation "shén guǐ jiāo fēng", meaning "when the spirits meet" adopted in Taiwan adhered to the four-character tradition adapted from Chinese idiom.

Example 9: The Mummy (1999)

Chinese Mainland: 《木乃伊》

mù năi $y \bar{\imath}$

(The Mummy)

Taiwan:《神鬼傳奇》

shén guǐ chuán qí

(The Legend of the Spirits)

The Mummy is an American adventure film written and directed by Stephen Sommers. The story centers on an archaeological dig at the ancient city of Hamunaptra in which a curse was unleashed, and the mummy of the dead High Priest Imhotep was reanimated. Chinese Mainland's literal translation "mù năi y $\vec{\imath}$ ", meaning "the mummy" does not provide the viewers with any clues of the plot. Meanwhile, Taiwan's title adapted into "shén guǐ chuán qî", meaning "The Legend of the Spirits" leaves the viewers the impression of watching an adventurous journey involving spirits.

Example 10: Titanic (1997)

Chinese Mainland:《泰坦尼克号》

tài tăn ní kè hào

(Titanic)

Taiwan:《鐵達尼號》

tiě dá ní hào

(Titanic)

Titanic is an American epic romantic disaster film by James Cameron. It is a fictionalized account of the sinking of the RMS Titanic. The story centers on Jack Dawson and Rose DeWitt Bukater, the couple from different social classes who fall in love aboard the ship during its ill-fated maiden voyage. The transliteration performed in Chinese Mainland "tài tăn ní kè hào" is phonologically closer to the original title; while the translation "tiě dá ní hào" in Taiwan is phonologically more compact in the target language.

Example 11: Independence Day (1996)

Chinese Mainland:《独立日》

dú lì ri

(Independence Day)

Taiwan:《Id4星際終結者》

Id4 xīng jì zhōng jié zhě

(Id4 The Interplanetary Terminator)

Independence Day is an American military science fiction film directed by German director Roland Emmerich. The story is about an alien invasion of Earth. A disparate group of people converged in the Nevada desert and participated in a last-chance counterattack on July 4. Chinese Mainland's literal translation "dú li ri", meaning "Independence Day" does not provide the viewers with any clues of what the film might be about. Such translation intrigues the viewers' curiosity, and serves the commercial purposes for box office and film reception. On the other hand, Taiwan's adaptation "Id4 xīng jì zhōng jié zhe", meaning "Id4 The Interplanetary Terminator" gives the viewers the impression of a war. Notice Id4 stands for Independence Day of the United States of America which is on the fourth of July.

Example 12: Ghost (1990)

Chinese Mainland:《幽灵》

yōu líng

(Ghost)

Taiwan:《第六感生死戀》

dì liù găn sheng sĭ liàn

(The Sixth Sense Love Between Two Worlds) 
Ghost is an American romantic fantasy film written by Bruce Joel Rubin and directed by Jerry Zucker. The story centers on a young woman in jeopardy and the ghost of her murdered lover who tries to save her with the help of a reluctant psychic. Chinese Mainland's literal translation "yōu ling", meaning "ghost" may lead the viewer to believe Ghost is a horror film instead of a romance film. Meanwhile, Taiwan's adaptation "dì liù găn sheng sì liàn", meaning "the sixth sense love between two worlds" reflects the key elements of the film.

\subsection{The Translation of Film Titles in Chinese Mainland}

From the examples and their back translations, one may conclude that the film title translation norms in Chinese Mainland are more literal or direct; such as the case found in The Mummy. Literal translation, also known as word-forword translation or direct translation, is "ideally the segmentation of the source language text into individual words and target language rendering of those word-segments one at a time" (Baker, 2001: 125). Literal translation is the most common approach of translating proper nouns. If used properly, it could be an ideal and effective way of retaining the message of the source text while transmitting the message to the target audience.

Literal translation can be performed under the following circumstances. First, literal translation can be an appropriate strategy to apply since the constraints of time and space in subtitling do not allow translators to use superfluous words or sentences to explain or polish the translated sentences. Second, when the cultural or linguistic messages in the source language can be presented in the most possible way without bewildering the audience, literal translation is also attainable. Hence if a translator is asked to translate the following line from the film: "They were following orders from 10 Downing Street", for most cases, the translator might choose to retain "They were following orders from 10 Downing Street." as it is.

Religious or spiritual terms are often omitted or overlooked in Chinese Mainland such as the case of Ghost. In film translation, "a culture-specific reference does not exist of itself, but as the result of a conflict arising from any linguistically represented reference in a source text which, when transferred to a target language, poses a translation problem due to the nonexistence or to the different value (whether determined by ideology, usage, frequency, etc.) of the given item in the target language culture" (Aixelá, 1996: 57). Culture-specific references of film translation are elements from the source culture which do not exist in the target community. It is integrated in the source culture, which reflect and carry the culture of the source community as a whole. Aixelá (1996) believes that a culture-specific reference can be identified only when supplied with reference of a particular source language and a particular target language.

There is always "some loss and distortion in verbal communication since no two interlocutors ever have exactly the same designative and associative meanings for the same phonological, lexical, grammatical, and discourse features" (Nida, 1993: 118), and film is a media for mass communication. Thus film translators should ensure that the target audience will not just only comprehend, but appreciate the foreign film in almost a similar way that the source text audience do. There is no absolute one to one correspondence between languages. Hence, Nida stressed, "equivalence can be understood in terms of proximity, i.e. on the basis of degrees of closeness to functional identity" (Nida, 1993: 117). Thus, Nida's theory of functional equivalence serves as a guideline for film translators for film translators' primer goal should always be striving to provide the target audience with a faithful, comprehensible, and natural translation.

Relevance theory explains the implicit inferences or second method of communication. It argues that people can communicate because people are capable of drawing inferences through one's behavior, and that inferences people make as hearers in a communication arise from the tacit expectation that the speaker follows the principle of relevance for "every act of ostensive communication communicates the presumption of its own optimal relevance" (Sperber and Wilson, 1986: 258). Achieving relevance is to allow the latest information to be transmitted within the context with the maximum contextual effect, on the basis of the least amount of effort in processing required to convey it. It claims that people instinctively react to an encoded message by considering information that it conceives to be relevant to the message. It suggests communication is inferential, where content is interpreted rather than decoded. It is less concerned with finding equivalences, and allows greater scope for variances between the source and target texts.

Relevance is also context-dependent. In 2000, Gutt claims that relevance theory offers theoretical foundations for "accounting for translation in terms of the communicative competence assumed to be part of our minds" (Gutt, 2000: 21). Gutt believes equivalence is not the most basic concept in translation. It is a special case of a more general notion of adequacy for "its domain is mental faculties rather than texts or processes of text production" (Gutt, 2000: 21). Thus, "there is no aspect of the original that will necessarily have to be preserved in translation [...]" (Gutt, 2000: 16). It is the translator's aim to establish a pattern of norms needing to be retained in translation.

When should the translator omit the content? Leppihalme (1994:93) points out that "a translator may responsibly choose omission, after rejecting all alternative strategies, or irresponsibly, to save him/herself the trouble of looking up something s/he does not know". The common omission can be found regarding a song, an utterance, a redundant expression, a minor detail, the title of a character, or repeated phrases when the source language itself is dense. It is impossible to translate it in detail because doing so may result in subtitles that become too long and cause confusion and eye-tracking incompetency for the audience. Omission of the culture-specific content is made for the ease of the target audience when there is an absence of a corresponding carrier of a meaning component to that of the source text in the surface structure of the target text. It is also performed when the film translators do not have active competence in both the source and the target languages. Hence, the culture-bound references become omitted, and as a result, it becomes difficult for the target community who lacks the knowledge of cultural information to understand the culture-bound

\footnotetext{
${ }^{8} 10$ Downing Street is the official site of the British Prime Minister's Office.
} 
contents. Thus, the sentence "They were following orders from 10 Downing Street." should be translated as: "They were following orders."

In Chinese Mainland, thriller, horror, and action films more favor the additional use of Chinese cultural terms, heroic animals: dragon, tiger, etc such as in the case of Live Free or Die Hard (2007)《虎胆龙威4.0》(Tiger's Courage, Dragon's Power). Addition is used when literal translation or adaptation cannot be applied. The translator tries to make up for the loss during the process of film translation through amplification. Translators add words when the original text requires explanation to help clarify implied meaning for the target audience. By amplifying and reshaping the sentence structure of the original message, the translated text could look or sound more viewer-friendly.

The key to addition is to add words to explicate the text without twisting or changing the original meanings. It is applicable when the dialogue in the source language is too succinct to use condensation, or that the meaning behind the original text cannot be fully conveyed through literal translation or paraphrasing. Hence, when the source text requires further explanation because some cultural meaning is not equivalent in the target language, addition is needed. Thus, "They were following orders from 10 Downing Street." should be translated as: "They were following orders from 10 Downing Street, the Prime Minister's House.", which includes an explanation of what is the "10 Downing Street".

4.2 The Translation of Film Titles in Taiwan

The film title translation norms in Taiwan seem to follow a more strategic recreation policy according to its genre. Films categorized under romance such as Ghost would often be translated as: 真情，真愛(true love), 夜未眠 (sleepless night), and 生死戀 (love between two worlds). Adventurous films such as The Mummy would be translated as 神鬼 (spirits or devil \& God) and 火綫 (fire line). Thriller, horror, and action films such as Live Free or Die Hard are in favored of 警探 (agent), 致命 (lethal), and終極 (ultimate).

Film translation is a branch of literary translation which constantly undergoes the process of recreation. Recreation is a very complex and abstract concept. Holmes believes apart from the general tendency to favor domestication in translating texts at the linguistic level, there is also an opposing trend in favor of "historicizing and exoticizing in the socio-cultural situation" (Holmes, 1988: 49) among translators. A good recreation is the maximum incorporation of the culture-specific references of the source text into the target text. In order to accomplish this fusion, the film translator should have a complete command of the source language, and also acquire a profound knowledge on the culture and history of the source community.

Beauty stems from creation. Recreation is frequently adopted in film translation due to the wide variety of the target audience. It is therefore the film translator's duty to produce a viewer-oriented comprehensible version because the purpose of recreation is not just to reproduce the film faithfully, but to reproduce the artistic reality embodied in the film. Therefore, the focus of translation is not solely on the language, but artistic reality. The aesthetic value of a film translation depends on how film translators artistically recreate and fill up the cultural gap. However, this creation is a kind of special artistic recreation which should be based upon the author's creativity. The translator neither submits to the original text, nor translates freely without considering the original text. The translator tries to make alteration within the given space of the overlapping parts of the source text and target text.

In film translation, when performing the translation of terms with foreign characteristics, translators tend to adopt the creative approach. By creating a new term, the translator is able to convey more vivid ideas. Hence, translators should do the creative work when there are no conventional expressions to borrow or similar expressions to be adapted from English.

During the course of translating, the translator often develops his or her subjectivity when he or she interprets the original utterances as a reader and scholar. The translator's linguistic choices and pragmatic translation methods must focus on delivering the original messages without putting the audience to unnecessary processing effort in achieving the contextual efforts in the interpretation.

It is critical for the translator to consider the values and customs of the target language, which is not an isolated phenomenon but an integral part of a culture. One of the most important factors that determine a translation purpose is the intended audience in the target language and culture for communicative needs. Therefore, the translators should adopt the viewer-oriented principle in order for the target audience to fully understand the film in its original language. A possible recreation of the sentence: "They were following orders from 10 Downing Street." could be: "They were following orders from the Big Brother.", which in English, is a fictional character created by George Orwell in 1984; and in Mandarin stands for an elder brother, or chief.

In film translation, similar cultural setting is transferred by the translator from the source culture into the target culture. Chinese Mainland and Taiwan clearly have very different policies for the translation of film titles. Translators across the Strait follow different translation conventions for the translations. Chinese Mainland's translations tend to be more literal, and some times may be word-by-word direct translations without considering the commercial impact. Whereas, Taiwan's translations often adhere to the four-character convention, and often is consisted of catchy expressions or idioms that produce commercial effect. In general, in order to perform good translations of the film titles for the viewers, when performing the translation, the translators should try to maintain the transposition of the cultural loaded terms at the discourse and textual levels, accommodate the target readership environment and their logic and thinking patterns in order to create its commercial value. Meanwhile, the organization of the linguistic expression must be adapted to accommodate target readership thinking patterns. Gutt proposes that:

Thus, if we ask in what respects the intended interpretation of the translation should resemble the original, the answer is: in respects that make it adequately relevant to the audience, that is, that offer adequate contextual effects; [...] it should be expressed in such a manner that it yields the intended interpretation without putting the audience to unnecessary processing effort (Gutt, 2000: 107). 


\section{Problems and Challenges}

Mistranslation occurs when the translator attempts to recreate excessively without taking the original text into consideration. It is a mistreatment of the original text and this would fail to convey the original message of the film to the target audience. As stated by Gutt (2000: 113), the translator "does not have direct access to the cognitive environment of his audience [...] all he can have is some assumptions or beliefs about it". Such mistreatment is mainly caused by the translator's language deficiency and the lack of cultural and historical knowledge. Therefore, in order to avoid mistranslating, translators are demanded to acquire not only complete fluency of the source language, but also has to have sufficient knowledge on the culture and history of the source language.

In the translation of the film title of Catch Me If You Can (2002), the translators in Chinese Mainland and Taiwan clearly took very different approaches. The translator in Chinese Mainland translated the title into 我知道你是谁 (I Know Who You Are), which is a disputable translation because the officers do not necessarily have the clue to the identity of the suspect. Hence, such mistranslation may mislead the audience into believing that there is a clear target that the officers are after. However, on the other hand, the translation of the same title across the Taiwan strait is神鬼交鋒 (When Devil Meets God). This translation does not identify the two sides, but rather gives an overview of the tension between them. Furthermore, the translation strategy in Taiwan used the term神鬼 (spirits or devil \& God) which is very common.

Which method should be adopted for film translation when it comes to the transmission of culture-specific terms? The choice depends on the culture-specific terms themselves, but mutual adaptability between the methods is necessary for film translation. Different translation theories must be applied to different texts in a film. Film translation is a way of transmitting, distributing, and regulating cultural capital. The ultimate purpose of translation is the transfer of the source information to its receivers. Therefore, the latest information must be transmitted within the source context with the maximum contextual effect on the basis of the least amount of effort in processing required to convey it. Thus in order to create a harmonious film translation favored by the target audience, functional equivalence, relevance theory, and reception theory must all be taken into account by translator during the translation process to produce an optimal version, deliver the culture-specific content, and to deal with cultural differences. Merely by applying literal translation with regards to adequacy, the essence of the film can be lost, and the message may fail to be delivered to the audience.

According to Baker (2001), the descriptive translation studies and the pure theoretical translation studies have the character of being non-language-specific, and the similarity of the development of some translation theoretic compatibility. Thus, they emphasize the integrative characteristics of translation. Therefore, it is only when the translator has maintained these qualities with the bonding of the methods aforementioned can the film translation be truly adequate and viewer-friendly.

The phenomenon of low quality translation can be attributed to the following reasons. Translators across the Strait do not have a set of universal criteria or principles to follow, and have simply work by convention during film translation. Furthermore, the key factor in film translation is time limit. Unlike translating a foreign novel, the task of film translation is rather more urgent due to the audience's demand of the latest films displayed internationally. One amateur may be given a longer period of time to translate a book written in a foreign language, while a professional film translator must complete his or her work under the pressure of tight deadlines; often at a short notice. The film translators in Chinese Mainland and Taiwan today are often hired by the film distributors on a case-by-case basis. Most of them are not exclusive professional translators of the film industry, and remain anonymous to the public. Furthermore, studies in the field of film translation cannot keep pace with the popularity and prosperity of foreign films, and there are no systematic guidelines to follow.

Untranslatability is a common problem which every translator must face. It is a property of a text, wherein one language has no equivalent counterparts in another language. A text that is considered to be untranslatable is sometimes a lacuna, or a lexical gap. Meaning, there is no direct equivalence between the text in the source language and another text in the target language. According to Catford (1965), there are two forms of untranslatability: cultural untranslatability and linguistic untranslatability. Cultural untranslatability is often found in culture-specific terms, while linguistic untranslatability often has to do with the aesthetic elements found in an expression. However, a translator with a good command of bilingual abilities and bicultural awareness can resort to a number of translation procedures for compensation. The purpose of translation is to communicate, and the degree of difficulty of translation depends on the nature of the text and the translator's abilities. Therefore, in order to serve the function of communicating and bridging the gaps between different language communities, the film translator should try to retain the original spirit of the film so that the message in the source language could be passed onto the target audience, and the culture-specific contents could be transformed into that of the equivalent known to the target audience.

According to Newmark (1988: 46), adaptation is the freest form of translation, which is used mainly for plays and poetry wherein the themes, characters, plots are usually preserved, and the source language culture is converted to the target language culture and the text is rewritten.

In film translation, it is also often necessary and useful to use the method of paraphrasing, especially when there is no linguistic form or cultural equivalence in the target language to express the exact messages in the source language. Paraphrasing is "a term for loose rewording, saying something in your own words" (Baker, 2001: 166). Instead of translating the source language word-for-word, paraphrasing allows translators to translate more freely by explaining the original words or phrases based on the context with the use of the target language. Alongside, paraphrasing can also be applied in the translating of metaphors or allusions because annotation makes the translated text wordy. Not being able to entirely transfer the message of the source text to the target language, paraphrasing sometimes may lead to a loss of the original flavor. However, it can still generate a certain degree of resemblance. 


\section{Conclusion}

Film translation is a viewer-oriented activity. As the appreciation of films becomes a globalized activity, films become more and more influential for spreading culture-specific values, ideas, and information than ever. The purpose of film translation is to transfer the culture that underlies in the message of the film language, and to attract the audience by presenting the aesthetic value and thus amplify the business value of the film. Film translation has enhanced the exchange between different languages and cultures. The requirements of intercultural communication can often be best solved by close adhesion to established translation theories and suggested methods. The more precise the translation is, the more authentic the translation will be. The translation chosen by film translators will greatly contribute to the reception of a source language by the target culture. Therefore, the training of film translators under such context is extremely important.

Variance in form should be a conscious accommodation of the thinking patterns of the target language audience reflecting the receptor's logic and cognitive structuring. Idioms, parodies, proverbs, puns, and slangs of the source language must be translated accordingly into the target language, and the culture-specific words must be carefully treated. The combination of the different translation methods would aid the perception of the viewer, along with the integrative characteristics of translation theories will help preserve specific cultural appeal and transmit it to the target audience.

Generally, this paper has given an overview of the film translation across the strait. It presents several new aspects for the study of film translation. The primitive translation methods discussed could serve as fundamental principles for film translation. Alongside, the analysis of the application of the different translation methods shows the need for wellcombined translation methods.

Viewing a foreign film that has undergone translation is always both subjective and objective. The relevance theory fails to account for the text function of expanding the viewers' understanding. Viewers could hold their own ideas and values gained from their personal experiences, but still at the same time gaining new understanding through the film.

Film translators will continue to face the challenge of preserving specific cultural appeal and transmitting it to the target community due to the scarcity of translation resources. The translation chosen by film translators will greatly affect the reception of a source language in a target culture. Therefore, it is important to have an accurate, brief, and vieweroriented translation. It is the translator's role to formulate a translation that is viewer-oriented, which includes what is vital under the constraints of time and space by maintaining the harmonious balance between sounds and visuals in film translation so that the wide variety of audience can comprehend.

Film will continue to be one of the most well received media for cultural transfer. As more exchanges take place, the demand of good film translation will increase. In order to produce high quality and efficient film translations, studies of developing common translation methods should be developed in order to produce universal film translation strategies.

\section{References}

Aixelá, J. F. (1996). Culture-specific Items in Translation. In Alvarez, R., \& Vidal, M. C. Translation, Power, Subversion. Clevedon: Multilingual Matters Ltd.: 52-78.

Baker, M. (1992). In Other Words: A Coursebook on Translation. London and New York: Routledge.

Baker, M. (Ed.). (2001). Routledge Encyclopedia of Translation Studies. London and New York: Routledge.

Catford, J.C. (1965). A Linguistic Theory of Translation. London: OUP.

Chen, S-J. (2004). Linguistic Dimensions of Subtitling. Perspectives from Taiwan. Meta: Translators' Journal, 49(1):

115-124.

Dollerup, C. (1974). On Subtitles in Television Programmes. Babel, 20(4): 197-202.

Gambier, Y. (2003). Screen Transadaptation: Perception and Reception. The Translator, 9(2): 171-190.

Gottlieb, H. (2000). Screen Translation: Six studies in Subtitling, Dubbing and Voice-over. Copenhagen: Center for Translation Studies, University of Copenhagen.

Guo, M. (1984). Lun Wenxue Fanyi Gongzuo, Fanyiyanjiu Lunwenji (On Work of Literary Translation. Collected Papers on Translation Studies) (1949-1983). Beijing: Foreign Language and Research Press.

Gutt, E-A. (2000). Translation and Relevance: Cognition and Context (2nd ed.). Manchester: St. Jerome Publishing. Holmes, J. S. (1988). Translated! Papers on Literary Translation and Translation Studies. Approaches to Translation Studies, 7. Amsterdam: Rodopi.

Jakobson, R. (1959). On Linguistic Aspects of Translation. In Brower, R. A. On Translation. Cambridge, MA: Harvard University Press: 232-239.

Kovačič, I. (1994). Relevance as a Factor in Subtitling Reductions. In Dollerup, C., \& Lindegaard, A. Teaching

Translation and Interpreting 2. Amsterdam and Philadelphia: John Benjamins: 245-251.

Leppihalme, R. (1997). Culture Bumps: On the Translation of Allusions. Helsinki: Clevedon: Multilingual Matters Ltd. Li, Y. (2001). Strategies for Translating Subtitles. Chinese Translators Journal, (4): 38-40.

Liu, M. (1999). Dangdai Fanyi Lilun (Contemporary Translation Theories). Beijing: China Translation \& Publishing Corporation.

Nedergaard-Larsen, B. (1993). Cultural-bound Problems in Subtitling. Perspectives: Studies in Translatology, 1(2): 207-241.

Newmark, P. (1988). A Textbook of Translation. New York and London: Prentice Hall.

Nida, E. A. (1964). Towards a Science of Translating. Leiden: E.J. Brill.

Nida, E. A. (1993). Language, Culture and Translating. Shanghai: Shanghai Foreign Language Education Press.

Qian, S. (2004). The Present Status of Screen Translation in China. Meta: Translators' Journal, 49(1): 53-58. 
Sperber, D., \& Wilson, D. (1986). Relevance: Communication and Cognition. Oxford: Blackwell.

Statistics Shanghai. 22.13 Production, Dubbing and Showing of Films (1978 2010) [EB/OL]. [2012-02-20].

http://www.stats-sh.gov.cn/tjnj/nje11.htm?d1=2011 tjnje/E2213.htm.

Taiwan Cinema. [EB/OL]. (2012 01-16) [2012-02-20].

http://www.taiwancinema.com/IVaTrackback/trackback.asp?id=132.

Trosborg, A. (1997). Text Typology and Translation. Amsterdam and Philadelphia: John Benjamins.

Varela, F. C. (1998). Textual Constraints and the Translator's Creativity in Dubbing. // Beylard-Ozeroff, A. Králová, J., \& Moser-Mercer, B. (Eds.). Translator's Strategies and Creativity. Amsterdam and Philadelphia: John Benjamins.

Yan, F. (2009). Tianyanlun (Evolution and Ethics). Beijing: China Youth Publishing Group.

Yeh, Y-Y., \& Davis, D. W. (2005). Taiwan Film Directors: A Treasure Island. New York: Columbia University Press. Zhang, C. (1998). Yingshi Fanyi Chutan (On China Audiovisual Translation). Chinese Translators Journal, (2): $50-53$. Zhao, C. (2000). Translation into Chinese of Film Scripts and Scripts of TV Drama Series - Four Main Conflicting Demands. Chinese Translators Journal, (4): 49-51. 